\title{
Barium Aluminate Hydrates
}

\author{
By Elmer T. Carlson and Lansing S. Wells
}

\begin{abstract}
Methods of preparation, optical properties, and X-ray diffraction data are reported for six barium aluminate hydrates. Three of these were obtained successively by precipitation from supersaturated barium aluminate solutions at $30^{\circ} \mathrm{C}$. The first, designated by the empirical formula $1.1 \mathrm{BaO} \cdot \mathrm{Al}_{2} \mathrm{O}_{3} \cdot 6 \mathrm{H}_{2} \mathrm{O}$, is metastable with respect to the second, $\mathrm{BaO} \cdot \mathrm{Al}_{2} \mathrm{O}_{3 .-}$ $7 \mathrm{H}_{2} \mathrm{O}$, which in turn is metastable with respect to $\mathrm{BaO} \cdot \mathrm{A1}_{2} \mathrm{O}_{3} \cdot 4 \mathrm{H}_{2} \mathrm{O}$. Two lower hydrates, $\mathrm{BaO} . \mathrm{Al}_{2} \mathrm{O}_{3} \cdot 2 \mathrm{H}_{2} \mathrm{O}$ and $\mathrm{BaO} \cdot \mathrm{Al}_{2} \mathrm{O}_{3} \cdot \mathrm{H}_{2} \mathrm{O}$, were prepared hydrothermally. $2 \mathrm{BaO} \cdot \mathrm{Al}_{2} \mathrm{O}_{3} \cdot 5 \mathrm{H}_{2} \mathrm{O}$ was obtained from boiling barium aluminate solutions.
\end{abstract}

\section{Introduction}

For several years, the calcium aluminates and their hydration products have been studied by a number of investigators in various countries. The widespread interest in these compounds resulted chiefly from their importance in relation to hydraulic cements. In spite of the large amount of work that has been done, it cannot be said that the relationships of the various hydrated calcium aluminates are fully established. Among the difficulties connected with the problem are the low solubilities of the hydrates, extreme fineness of precipitates, slowness of approach to equilibrium, and persistence of metastable phases.

In view of these difficulties it was considered possible that a study of the aluminates of barium might disclose a series of analogous compounds from which might be drawn some inferences as to the nature of the calcium aluminates. It was known that the solubilities of the barium compounds were much higher, and it seemed not unlikely that the other difficulties might also be minimized. During the course of this investigation it soon became apparent that the hydrated aluminates of barium were in no way analogous to those of calcium; nevertheless, the study was continued because of the importance of the barium compounds themselves. The barium aluminates have found application in water purification, and it has been proposed that barium compounds might replace those of calcium in cements for special purposes.

The hydrated barium aluminates have been studied by several investigators, notably E. Beckmann [1] ${ }^{1}$ and G. Malquori [2]. The latter gives a solubility diagram for the system $\mathrm{BaO}$ $\mathrm{Al}_{2} \mathrm{O}_{3}-\mathrm{H}_{2} \mathrm{O}$ at $20^{\circ} \mathrm{C}$, and indicates that the compounds $\mathrm{BaO} . \mathrm{Al}_{2} \mathrm{O}_{3} \cdot 6 \mathrm{H}_{2} \mathrm{O}$ and $2 \mathrm{BaO} . \mathrm{Al}_{2} \mathrm{O}_{3} \cdot 5 \mathrm{H}_{2} \mathrm{O}$ occur as primary phases at this temperature. Beckmann reports a compound $3 \mathrm{BaO} \cdot \mathrm{Al}_{2} \mathrm{O}_{3} \cdot \mathrm{XH}_{2} \mathrm{O}$, in addition to the other two, and the $\mathrm{BaO}: \mathrm{Al}_{2} \mathrm{O}_{3}$ ratio of the 1:1:6 compound is said to be variable. Neither optical nor X-ray data were found in the literature for any of the barium aluminate hydrates.

\section{Methods}

The general method used in the present investigation was similar to that employed in the study of the calcium aluminates [3]. Supersaturated solutions of alumina in barium hydroxide were prepared and allowed to stand, with occasional shaking, at $30^{\circ} \mathrm{C}$. The precipitates were observed under the microscope from time to time, and changes in concentration of the solutions were determined by analysis. Various methods were used for preparation of the supersaturated solutions. The most satisfactory was the treatment of anhydrous barium aluminate with sufficient water to cause practically complete hydrolysis and precipitation of hydrated alumina, followed by boiling with barium hydroxide solution to dissolve the alumina. The solution was then filtered promptly while still hot. The anhydrous aluminate used for the purpose was either $\mathrm{BaO} \cdot \mathrm{Al}_{2} \mathrm{O}_{3}$

\footnotetext{
1 Figures in brackets indicate the literature references at the end of this paper.
} 
or $3 \mathrm{BaO} \cdot \mathrm{Al}_{2} \mathrm{O}_{3}$ or a mixture of the two, as desired, prepared by heating a mixture of barium carbonate and gibbsite $\left(\mathrm{Al}_{2} \mathrm{O}_{3} \cdot 3 \mathrm{H}_{2} \mathrm{O}\right)$, in the desired proportions, at about $1,300^{\circ} \mathrm{C}$. The products usually contained a little insoluble material, probably corundum, but this did not affect their usefulness.

Other methods of preparation of the solutions included treatment of gibbsite with boiling barium hydroxide solution, similar treatment of freshly precipitated alumina, and the interaction of barium hydroxide and aluminum sulfate in solution. Reagent grade chemicals were used except in the case of the gibbsite, which was a commercial product containing 0.30 percent of soda. Solutions were handled as rapidly as possible and flasks were tightly stoppered, but no other precautions were taken to avoid the action of carbon dioxide. Carbonation proceeded rapidly whenever the strongly basic solutions were exposed to the air, but the amount formed appeared insufficient to seriously affect the analysis of the solid phases.

The general procedure outlined above was designed to yield data from which a diagram of equilibrium at $30^{\circ} \mathrm{C}$ could be drawn. It has been found, however, that equilibrium in this system is not attained even after several months, and further work will be required before the equilibrium diagram can be established. The following generalizations may be made, however: (1) From solutions low in $\mathrm{BaO}$, hydrated alumina is precipitated as the primary phase; (2) From solutions sufficiently high in $\mathrm{BaO}$, hydrated barium hydroxide, $\mathrm{Ba}(\mathrm{OH})_{2} .8 \mathrm{H}_{2} \mathrm{O}$, is precipitated as the primary phase. The limiting concentration for this phase, with no alumina present, is about $50 \mathrm{~g}$ $\mathrm{BaO}$ per liter and increases somewhat with increasing alumina concentration; (3) From solutions intermediate in $\mathrm{BaO}$, three hydrated barium aluminates are precipitated successively, if the alumina concentration is about $15 \mathrm{~g} /$ liter or higher. From solutions lower in alumina, the second member of the series is formed directly. These three hydrates all have $\mathrm{BaO}: \mathrm{Al}_{2} \mathrm{O}_{3}$ ratios close to $1: 1$. The fact that they are sometimes formed in contact with solid $\mathrm{Ba}(\mathrm{OH})_{2} .8 \mathrm{H}_{2} \mathrm{O}$ suggests that no more basic barium aluminate hydrate exists as a stable phase at $30^{\circ} \mathrm{C}$.

In addition to the hydrates precipitated at $30^{\circ}$ $\mathrm{C}$, one compound was obtained from boiling solutions, as described below, and two were prepared by hydrothermal synthesis. In the latter procedure, the material to be treated was placed in a 3-ml platinum thimble, which was capped loosely and then placed in a bomb-type autoclave containing sufficient water to saturate the enclosed air at the temperatures used. The thimble was supported above the water level by means of a coiled wire in order to minimize the loss of dissolved substances. The autoclave was heated in a specially designed furnace [4] or, at the lower temperatures, in an ordinary laboratory oven.

In the chemical analysis of the products synthesized, the percentage of water was calculated from the ignition loss at $900^{\circ} \mathrm{C}$, with no correction for carbon dioxide. Microscopic examination indicated that the amount of carbonation was negligible. Alumina and barium oxide were determined by the usual gravimetric methods.

The refractive indices reported are for sodium vapor light. X-ray powder patterns were made on an X-ray spectrometer with a Geiger-counter and automatic recorder, using copper $\mathrm{K} \alpha$ radiation.

\section{Results}

The various hydrates synthesized are described below:

$1.1 \mathrm{BaO} \cdot \mathrm{Al}_{2} \mathrm{O}_{3} \cdot 6 \mathrm{H}_{2} \mathrm{O}$ - The compound that is precipitated first from highly supersaturated barium aluminate solutions, as described above, may be designated by this empirical formula. Analyses of six preparations indicated $\mathrm{BaO}: \mathrm{Al}_{2} \mathrm{O}_{3}$ ratios of $1.14,1.12,1.12,1.14,1.12$, and 1.11 , respectively. The ratios of $\mathrm{H}_{2} \mathrm{O}$ to $\mathrm{Al}_{2} \mathrm{O}_{3}$ in the same preparations were $6.1,6.2,6.0,6.1,6.0$, and 5.9. The slight variation in $\mathrm{BaO}: \mathrm{Al}_{2} \mathrm{O}_{3}$ ratio bore no observable relation to the concentration of the solution, and may be ascribed to experimental error. The departure from a 1:1 ratio is in agreement with the findings of E. Martin [5], who claims to have isolated a compound, $11 \mathrm{BaO}$. $10 \mathrm{Al}_{2} \mathrm{O}_{3} . x \mathrm{H}_{2} \mathrm{O}$. Beckman [1] and Malquori [2] also reported ratios greater than unity. The actual stoichiometric ratio remains in doubt. Thermal analysis indicates that most of the water is liberated below $160^{\circ} \mathrm{C}$.

This compound was precipitated from solutions of proper concentration, but formed rather slowly. From one solution in which the concentration of $\mathrm{Al}_{2} \mathrm{O}_{3}$ exceeded $17 \mathrm{~g} /$ /iter, precipitation commenced almost at once, but in more dilute solutions pre- 
cipitation was first observed after several days. Constant agitation appeared to have little if any effect at first, but probably accelerated precipitation after it had once started. The compound exists in the form of needle-shaped crystals (fig. 1)

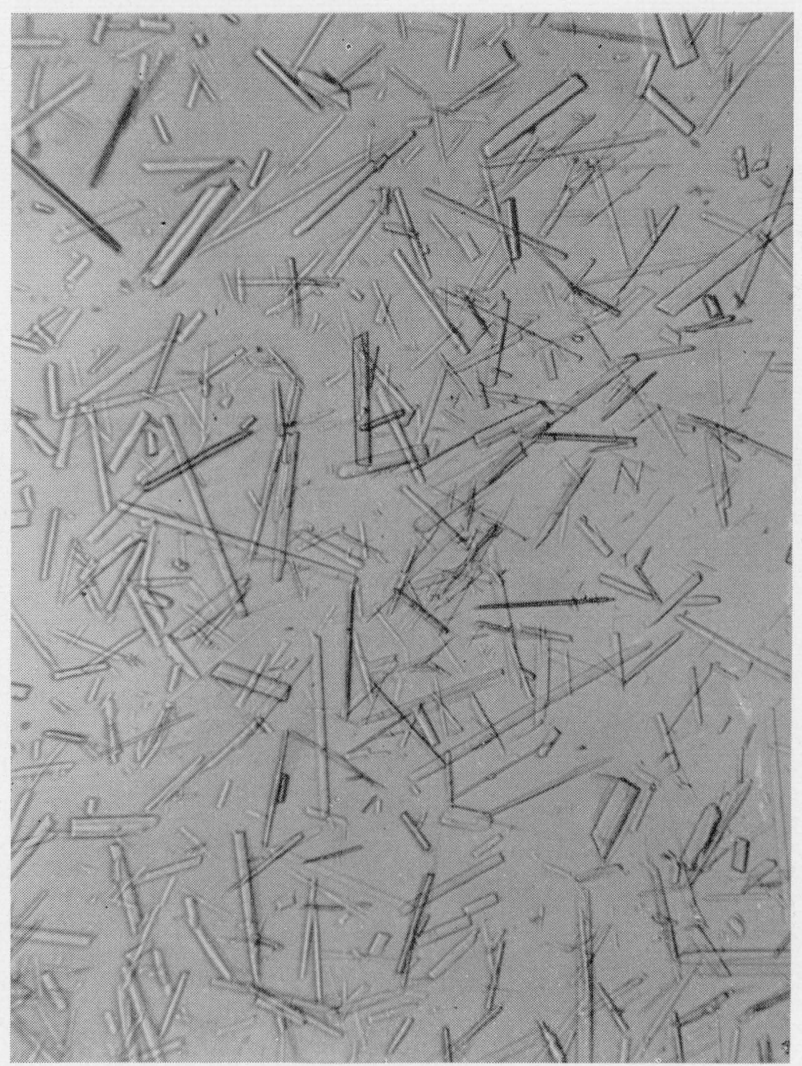

Figure 1. 1.1 BaO. $\mathrm{Al}_{2} \mathrm{O}_{3} \cdot 6 \mathrm{H}_{2} \mathrm{O}$

Magnification, $\times 120$.

and imparts to the reaction mixtures the "silky" appearance characteristic of crystals of this shape. Optically it is slightly birefringent, biaxial positive; $\alpha=1.535, \quad \gamma=1.540$; the elongation is positive. $\mathrm{X}$-ray diffraction data are given in table 1 .

Precipitation of this compound continues slowly for approximately a week, after which there appears a new crystal phase, described in the following paragraph. The needle crystals simultaneously disappear, and the excess $\mathrm{BaO}$ goes into solution. The transformation requires several days for completion, the time being somewhat variable.

$\mathrm{BaO} \cdot \mathrm{Al}_{2} \mathrm{O}_{3} .7 \mathrm{H}_{2} \mathrm{O}$ - This compound is produced by transformation of the 1.1:1:6 hydrate described above, and is also precipitated as the primary phase
TABLE 1. Interplanar spacings and relative intensities of $X$-ray diffraction bands for the barium aluminate hydrates

\begin{tabular}{|c|c|c|c|c|c|c|}
\hline \multicolumn{2}{|c|}{$1.1 \mathrm{BaO} . \mathrm{Al}_{2} \mathrm{O}_{3} .6 \mathrm{H}_{2} \mathrm{O}$} & \multicolumn{3}{|c|}{$\mathrm{BaO} . \mathrm{Al}_{2} \mathrm{O}_{3} .6 \mathrm{H}_{2} \mathrm{O}$} & \multicolumn{2}{|c|}{$\mathrm{BaO} . \mathrm{Al}_{2} \mathrm{O}_{3} .4 \mathrm{H}_{2} \mathrm{O}$} \\
\hline$d$ & Intensity & \multicolumn{2}{|c|}{$d$} & Intensity & $d$ & Intensity \\
\hline$A$ & & \multicolumn{2}{|c|}{$A$} & & $A$ & \\
\hline $10.7 \ldots$ & $\mathrm{S}$ & \multicolumn{2}{|c|}{ 7. 6} & $\mathrm{~S}$ & 5.46 & W \\
\hline $8.5 \ldots$ & VW & \multicolumn{2}{|c|}{ 4. 28} & M & 4. 91 & VS \\
\hline $6.0 \ldots$ & VW & \multicolumn{2}{|c|}{ 3. 74} & $\mathrm{~S}$ & 4.47 & VW \\
\hline 5.39 & $\mathrm{~s}$ & \multicolumn{2}{|c|}{ 3. 61} & W & 3.61 & VW \\
\hline $4.97 \ldots$ & VW & \multicolumn{2}{|c|}{ 3. 44} & VW & 3.22 & VS \\
\hline $3.99 \ldots$ & M & \multicolumn{2}{|c|}{ 3. 28} & M & 2.88 & W \\
\hline $3.61 \ldots$ & $\mathrm{VS}$ & \multicolumn{2}{|c|}{2.81} & VW & 2. 68 & M \\
\hline $3.39 \ldots$ & M & \multicolumn{2}{|c|}{ 2. 71} & W & 2.47 & VS \\
\hline $3.11 \ldots$ & M & & & S & 2.40 & VW \\
\hline $2.82 \ldots$ & M & & & 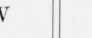 & 2. 28 & VW \\
\hline 2.72 & W & & & W & 2.15 & $\mathrm{~S}$ \\
\hline $2.61 \ldots$ & M & & & W & 2.10 & VW \\
\hline $2.48 \ldots$ & M & & & & 1.99 & W \\
\hline $2.25 \ldots$ & $\mathrm{S}$ & & & W & 1. 92 & W \\
\hline $2.16 \ldots$ & W & & & V & 1.82 & W \\
\hline $1.87 \ldots$ & W & & & W & 1. 69 & W \\
\hline $1.81 \ldots$ & M & $\ldots$ & & $\cdots$ & 1. 64 & VW \\
\hline 1.70 & M & $\ldots$ & & -.. & 1. 62 & W \\
\hline $1.55 \ldots$ & VW & $\cdots$ & & -.. & (n....... & -........ \\
\hline $1.40 \ldots$ & W & $\cdots$ & & & 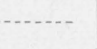 & -........ \\
\hline $\mathrm{BaO} \cdot \mathrm{Al}_{2} \mathrm{O}$ & $3.2 \mathrm{H}_{2} \mathrm{O}$ & $\mathrm{Ba}$ & $\mathrm{l}_{2} \mathrm{O}_{3} \cdot \mathrm{H}$ & s & $2 \mathrm{BaO}$ & $\mathrm{I}_{2} \mathrm{O}_{3} .5 \mathrm{H}_{2} \mathrm{O}$ \\
\hline$d$ & $\begin{array}{l}\text { Intens- } \\
\text { ity }\end{array}$ & $h k l$ & $d$ & $\begin{array}{l}\text { Intens- } \\
\text { ity }\end{array}$ & $d$ & $\begin{array}{l}\text { Intens- } \\
\text { ity }\end{array}$ \\
\hline$A$ & & & $A$ & & $A$ & \\
\hline $5.81 \ldots$ & W & 110 & 4.85 & $\mathrm{~S}$ & 6.31 & VS \\
\hline $4.56 \ldots$ & VW & 111 & 3. 94 & W & 3. 98 & M \\
\hline $3.86 \ldots$ & W & 200 & 3.42 & VS & 3. 76 & M \\
\hline $3.50 \ldots$ & M & 210 & 3.06 & W & 3.25 & M \\
\hline $3.37 \ldots$ & VW & 211 & 2. 79 & VS & 3.03 & VS \\
\hline $3.20 \ldots$ & $\mathrm{S}$ & 220 & 2. 42 & M & 2.89 & W \\
\hline $2.81 \ldots$ & W & 300 & 2. 28 & $\mathrm{~S}$ & 2. 71 & M \\
\hline $2.56 \ldots$ & V W & 310 & 2. 16 & M & 2. 60 & $\mathrm{~S}$ \\
\hline $2.33 \ldots$ & VW & 222 & 1. 97 & W & 2.51 & M \\
\hline $2.26 \ldots$ & VW & 320 & 1. 90 & VW & 2.37 & VS \\
\hline $2.09 \ldots$ & VW & 400 & 1. 71 & W & 2. 24 & W \\
\hline $1.98 \ldots$ & W & 410 & 1. 66 & VW & 2.09 & VS \\
\hline $1.91 \ldots$ & VW & 331 & 1. 57 & M & 2.03 & $\mathrm{~W}$ \\
\hline 1.75 & VW & 332 & $1.45^{\circ}$ & W & 1.81 & VW \\
\hline & & 500 & 1. 36 & M & 1. 76 & M \\
\hline & & 511 & 1. 31 & W & 1.66 & $\mathrm{~S}$ \\
\hline & & & cell: $a=$ & $81 \mathrm{~A}$ & 1. 61 & VW \\
\hline & & & & & 1.49 & VW \\
\hline & & & & . & 1. 43 & M \\
\hline
\end{tabular}

from solutions of somewhat lower alumina content. Three analyses of one preparation gave an average molar ratio of $0.97 \mathrm{BaO}: 1 \mathrm{Al}_{2} \mathrm{O}_{3}: 6.75 \mathrm{H}_{2} \mathrm{O}$. In another preparation, the ratio of $\mathrm{BaO}$ to $\mathrm{Al}_{2} \mathrm{O}_{3}$ was the same, but in two separate samples filtered off at different times, the ratio of $\mathrm{H}_{2} \mathrm{O}$ to $\mathrm{Al}_{2} \mathrm{O}_{3}$ was 6.80 in one case and 6.65 in the other. These samples had been washed with alcohol and ether, and it is believed that part of the water of 
crystallization is so loosely bound that it is removed by such treatment. Thermal analysis indicates that most of the water is driven off below $120^{\circ}$ C. Microscopic examination revealed the presence of a small amount of impurity believed to be hydrated alumina. This would explain the slight excess of $\mathrm{Al}_{2} \mathrm{O}_{3}$ over $\mathrm{BaO}$. The compound appears in the form of exceedingly thin flakes, approximately rectangular in outline (fig. 2). The crystals obtained were too small to permit a determination of optical character and sign. The indices of refraction are $\alpha=1.538, \gamma=1.556$. The elongation is positive. X-ray data are given in table 1.

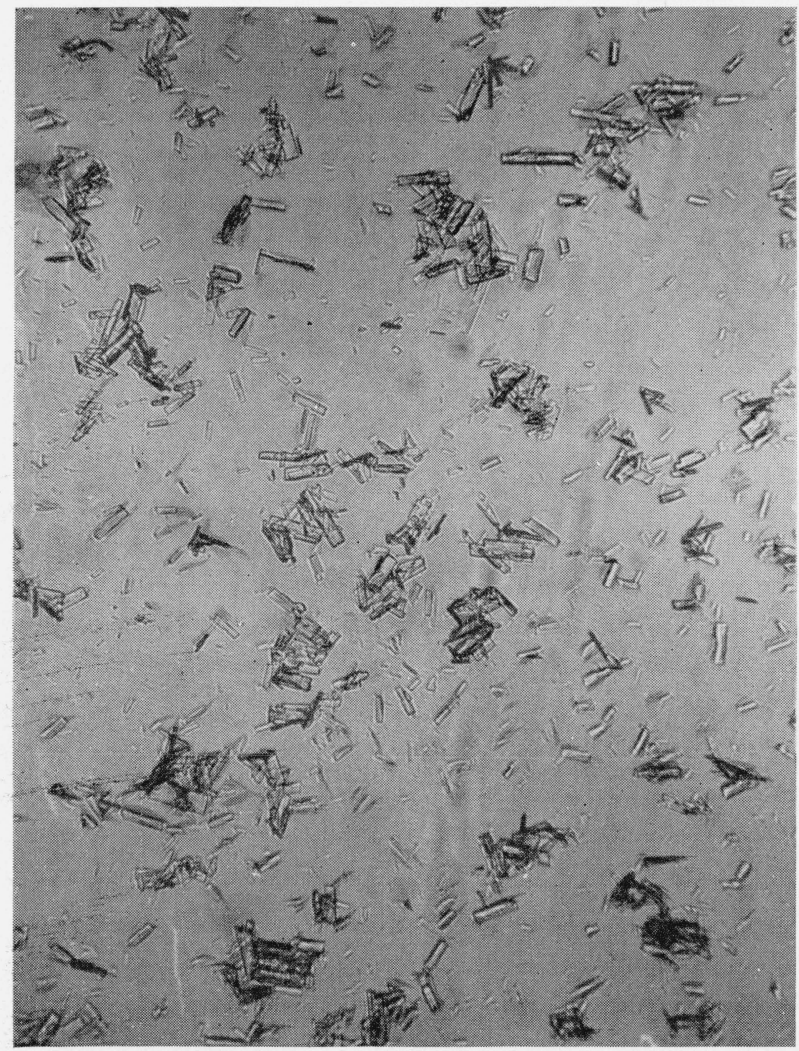

Figure 2. BaO. $\mathrm{Al}_{2} \mathrm{O}_{3} .7 \mathrm{H}_{2} \mathrm{O}$.

Magnification, $\times 120$.

On standing for several months, the reaction mixtures continued to precipitate this compound slowly until the concentration of $\mathrm{Al}_{2} \mathrm{O}_{3}$ was of the order of $8 \mathrm{~g}$ /liter.

$\mathrm{BaO} \cdot \mathrm{Al}_{2} \mathrm{O}_{3} \cdot 4 \mathrm{H}_{2} \mathrm{O}$ - This compound was first observed in one of the reaction mixtures described above. It had stood at $30^{\circ} \mathrm{C}$ for 4 months, and apparently a state of equilibrium had been reached between the solution and the precipitate of $\mathrm{BaO} . \mathrm{Al}_{2} \mathrm{O}_{3} .7 \mathrm{H}_{2} \mathrm{O}$. The new phase occurred as prismatic crystals, averaging $2 \mathrm{~mm}$ in length (fig 3 ). Because of their size, they were readily separated from the hexahydrate for examination and anal-

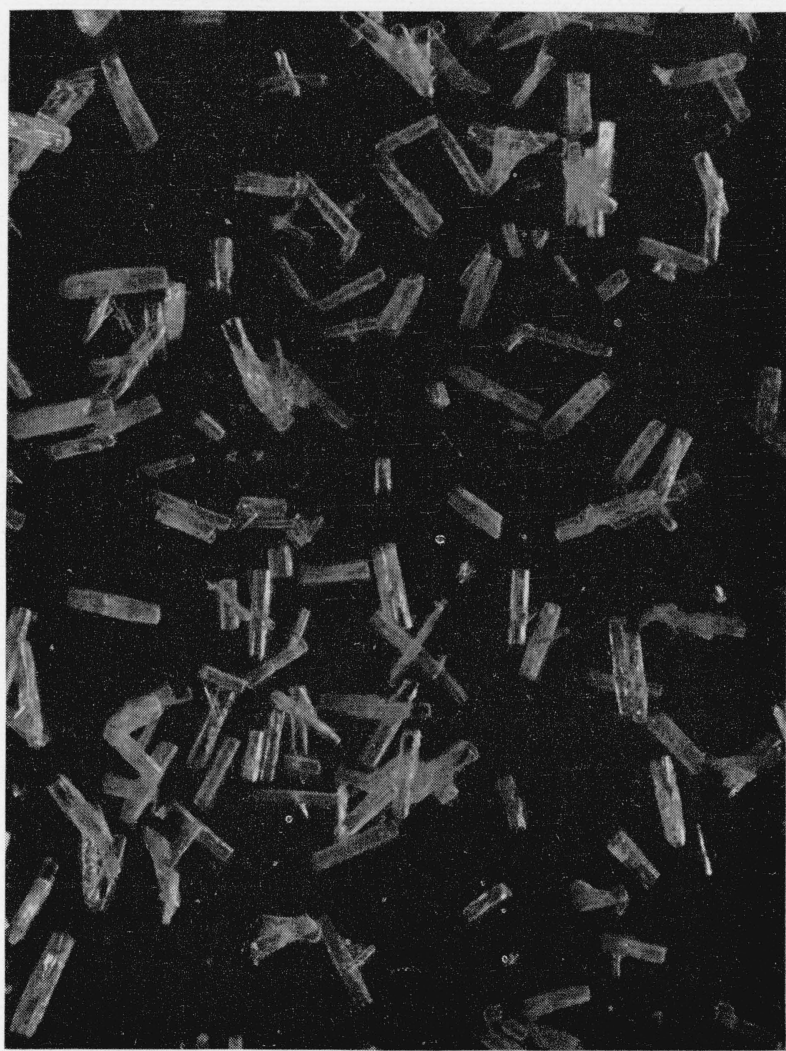

Figure 3. BaO. $\mathrm{Al}_{2} \mathrm{O}_{3} \cdot 4 \mathrm{H}_{2} \mathrm{O}$, prismatic form. Reflected light, magnification, $\times 5$.

ysis. The $\mathrm{BaO}: \mathrm{Al}_{2} \mathrm{O}_{3}: \mathrm{H}_{2} \mathrm{O}$ ratio was calculated to be $0.97: 1: 3.90$, from which it was assumed that the formula was $\mathrm{BaO} \cdot \mathrm{Al}_{2} \mathrm{O}_{3} \cdot 4 \mathrm{H}_{2} \mathrm{O}$. Later the same phase, in considerably different crystalline habit (fig. 4) appeared in several other reaction mixtures. X-ray diffraction and optical data showed it to be identical with the prismatic form. Analysis of two preparations gave the following ratios: $0.98 \mathrm{BaO}: 1 \mathrm{Al}_{2} \mathrm{O}_{3}: 3.94 \mathrm{H}_{2} \mathrm{O}$ and $0.99 \mathrm{BaO}: 1 \mathrm{Al}_{2} \mathrm{O}_{3}$ : $3.94 \mathrm{H}_{2} \mathrm{O}$. Refractiveindices of the tetrahydrate are $\alpha=1.625, \beta=1.628, \gamma=1.650$. It is biaxial positive. The crystals of prismatic habit are usually twinned. $\mathrm{X}$-ray data are given in table 1 .

The three compounds described above were the only barium aluminate hydrates formed at $30^{\circ} \mathrm{C}$ in any of the reaction mixtures studied. It is obvious that the first two are metastable with respect to the third, at least over a certain range 


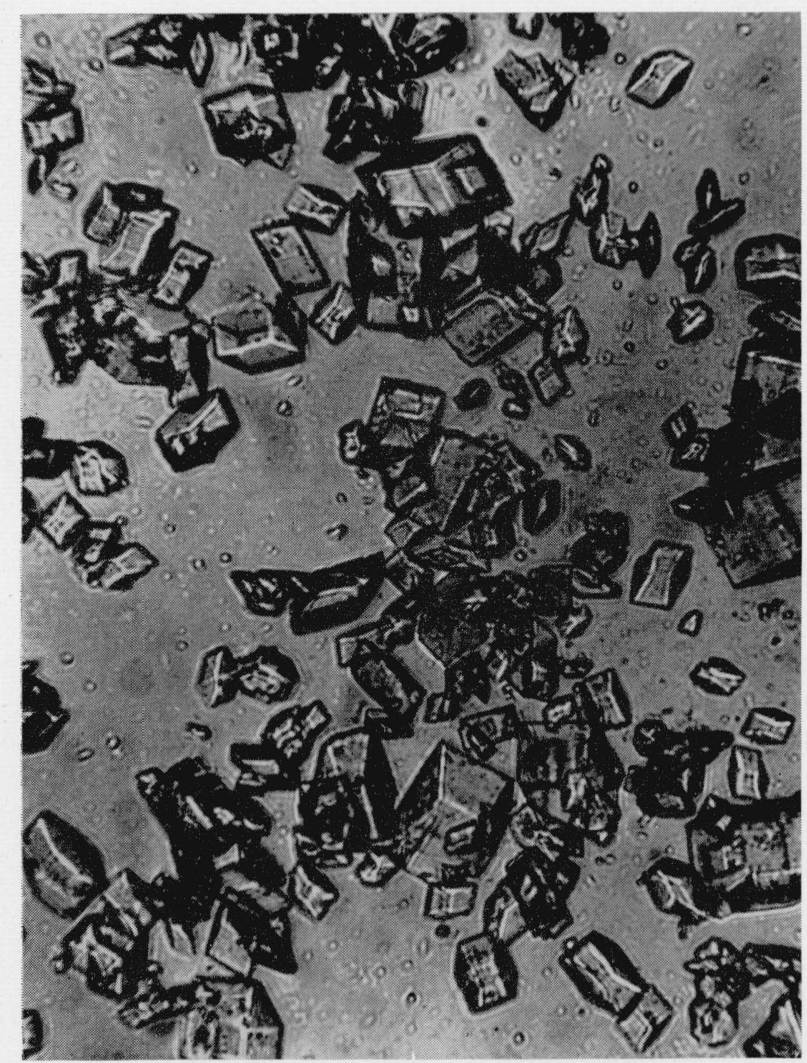

Figure 4. BaO. $\mathrm{Al}_{2} \mathrm{O}_{3} \cdot 4 \mathrm{H}_{2} \mathrm{O}$, rhombohedral form.

Magnification, $\times 250$.

of concentration not yet defined. It appears certain, also, that the heptahydrate is less stable at higher temperatures. This is supported by the following experiment. A sample of $\mathrm{BaO} \cdot \mathrm{Al}_{2} \mathrm{O}_{3}$.$7 \mathrm{H}_{2} \mathrm{O}$ in contact with barium aluminate solution was withdrawn from a reaction mixture that had stood for 4 months at room temperature without apparent change. The sample was held at $60^{\circ} \mathrm{C}$ for 7 days, at the end of which time it was found to have been changed completely to $\mathrm{BaO} \cdot \mathrm{Al}_{2} \mathrm{O}_{3} \cdot 4 \mathrm{H}_{2} \mathrm{O}$.

$\mathrm{BaO} \cdot \mathrm{Al}_{2} \mathrm{O}_{3} .2 \mathrm{H}_{2} \mathrm{O}-\mathrm{By}$ hydrothermal treatment of the heptahydrate preparation described in the preceding paragraph, a new crystalline compound was obtained. The molar ratio indicated by analysis was $0.99 \mathrm{BaO}: 1 \mathrm{Al}_{2} \mathrm{O}_{3}: 2.00 \mathrm{H}_{2} \mathrm{O}$; it may thus be considered a dihydrate of $\mathrm{BaO} \cdot \mathrm{Al}_{2} \mathrm{O}_{3}$. The same compound, with minor variations in crystal habit, was obtained from samples held at various temperatures ranging from $124^{\circ}$ to $215^{\circ} \mathrm{C}$, for periods of 2 to 4 days. (See table 2.) At lower temperatures the tetrahydrate was formed (see above), while at higher temperatures the monohydrate described below was produced.

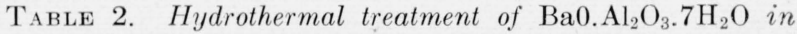
contact with barium aluminate solution

\begin{tabular}{|c|c|c|}
\hline $\begin{array}{c}\text { Tempera- } \\
\text { ture }\end{array}$ & $\begin{array}{c}\text { Duration of } \\
\text { treatment }\end{array}$ & Product \\
\hline${ }^{\circ} \mathrm{C}$ & Days & \\
60 & 7 & $\mathrm{BaO} \cdot \mathrm{Al}_{2} \mathrm{O}_{3} \cdot 4 \mathrm{H}_{2} \mathrm{O}$ \\
102 & 5 & Do. \\
124 & 4 & $\mathrm{BaO} \cdot \mathrm{Al}_{2} \mathrm{O}_{3} \cdot 2 \mathrm{H}_{2} \mathrm{O}$ \\
156 & 4 & Do. \\
175 & 3 & Do. \\
195 & 5 & Do. \\
215 & 2 & Do. \\
222 & 2 & $\mathrm{BaO} \cdot \mathrm{Al}_{2} \mathrm{O}_{3} \cdot 2 \mathrm{H}_{2} \mathrm{O}$ and $\mathrm{BaO} \cdot \mathrm{Al}_{2} \mathrm{O}_{3} \cdot \mathrm{H}_{2} \mathrm{O}$ \\
& & \\
228 & 2 & $\mathrm{BaO} . \mathrm{Al}_{2} \mathrm{O}_{3} \cdot \mathrm{H}_{2} \mathrm{O}$ \\
248 & 3 & Do. \\
295 & 6 & Do. \\
& &. \\
\end{tabular}

The dihydrate occurs as flat plates, usually grown together in foliated aggregates. A fragment of one of these aggregates is shown in figure 5, photographed under crossed nicols. The crystals are biaxial positive, with very low birefringence, and parallel extinction. The indices of refraction are: $\alpha=1.610 ; \gamma=1.613$.

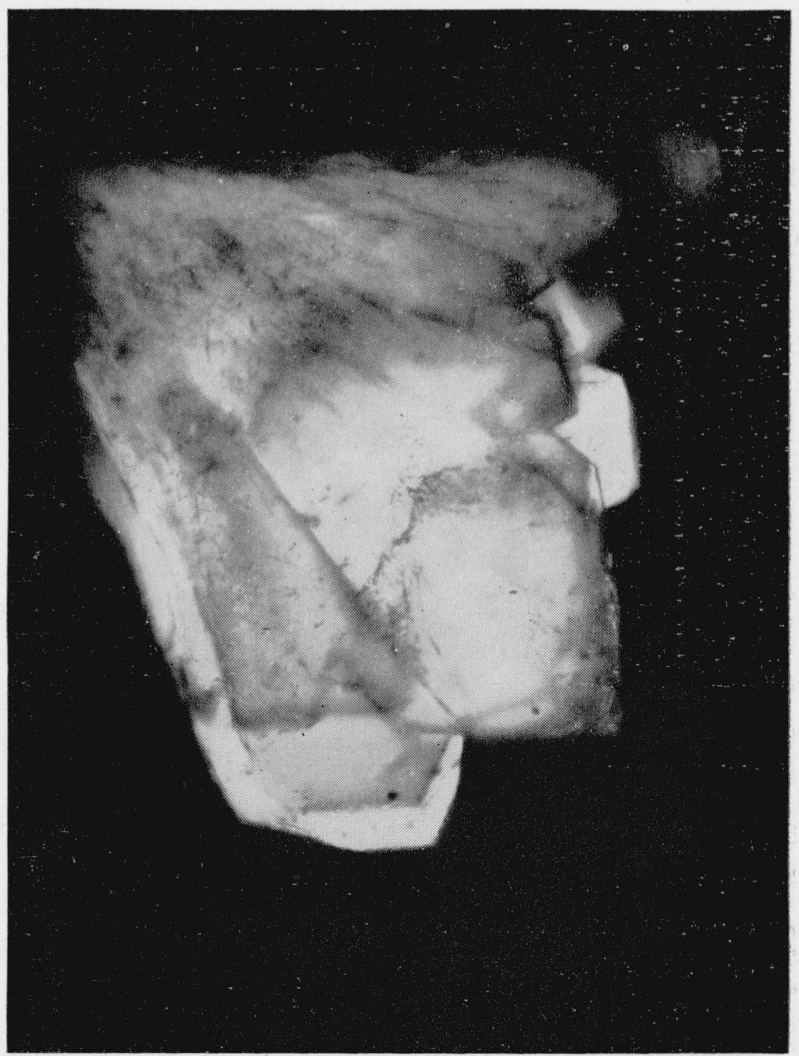

Figure 5. BaO. $\mathrm{Al}_{2} \mathrm{O}_{3} \cdot 2 \mathrm{H}_{2} \mathrm{O}$.

Crossed nicols, magnification, $x 100$. 
$\mathrm{BaO} \cdot \mathrm{Al}_{2} \mathrm{O}_{3} \cdot \mathrm{H}_{2} \mathrm{O}-\mathrm{A}$ crystalline compound (fig .6) approximating this formula was first obtained by hydrothermal treatment of anhydrous $\mathrm{BaO} \cdot \mathrm{Al}_{2} \mathrm{O}_{3}$ for 7 days at $275^{\circ} \mathrm{C}$. The same compound was later prepared in the same manner at temperatures ranging from $260^{\circ}$ to $350^{\circ} \mathrm{C}$, also by hydrothermal treatment of gibbsite in contact with $\mathrm{Ba}(\mathrm{OH})_{2}$ solution. In all cases there was a considerable amount of contamination by other substances, often unidentified. A better product was obtained by hydrothermal treatment of $\mathrm{BaO} . \mathrm{Al}_{2} \mathrm{O}_{3} .5 \mathrm{H}_{2} \mathrm{O}$ in contact with barium aluminate solution, at temperatures ranging from $222^{\circ}$ to $295^{\circ} \mathrm{C}$ (table 2). Similar treatment of $2 \mathrm{BaO} \cdot \mathrm{Al}_{2^{-}}$ $\mathrm{O}_{3} .5 \mathrm{H}_{2} \mathrm{O}$ (described below) at $280^{\circ} \mathrm{C}$ yielded the same compound. In this case the excess $\mathrm{BaO}$ remained in solution in the supernatant liquid. Analyses of three preparations gave the following molar ratios: $\mathrm{BaO}: \mathrm{Al}_{2} \mathrm{O}_{3}: \mathrm{H}_{2} \mathrm{O}=1.14: 1: 1.08$; $1.16: 1: 1.01 ; 1.12: 1: 0.99$. The relatively good agreement suggests that the departure from a $1: 1$ ratio may not be due to impurities, as was first

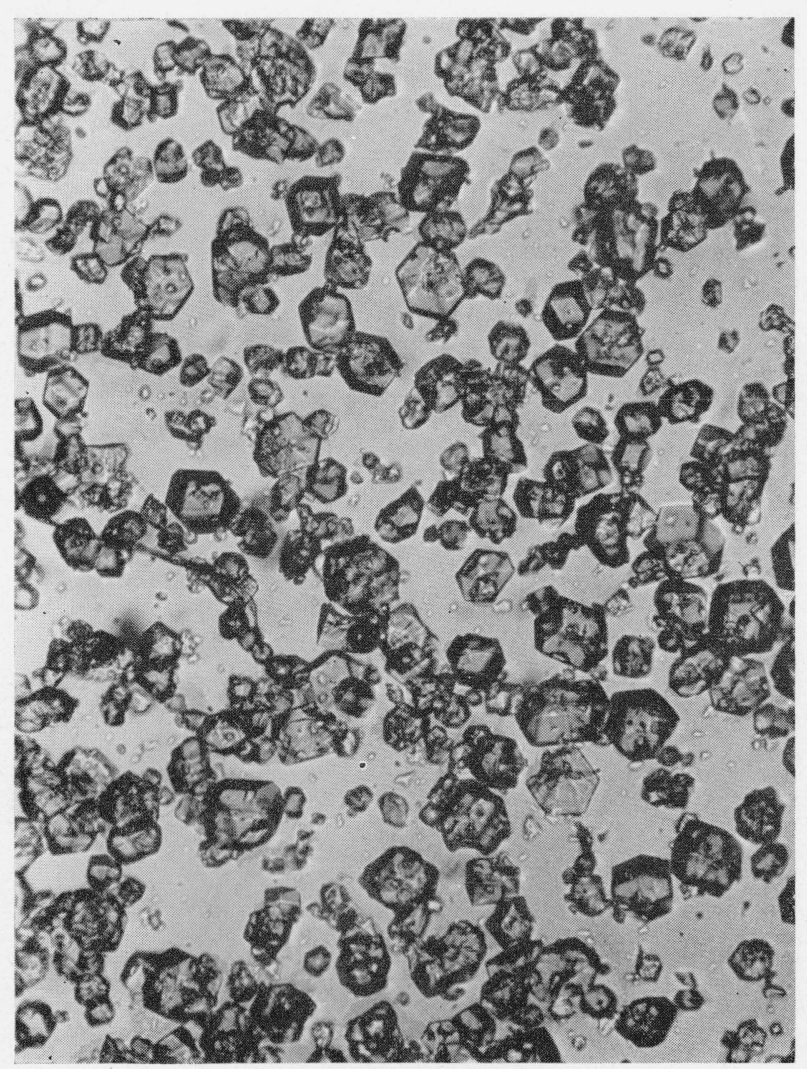

Figure 6. $\mathrm{BaO} \cdot \mathrm{Al}_{2} \mathrm{O}_{3} \cdot \mathrm{H}_{2} \mathrm{O}$.

Magnification, $\times 120$ believed. It may indicate, instead, that the simple formula given is incorrect, or that solid solution may occur. In the absence of further evidence, however, the formula $\mathrm{BaO} \cdot \mathrm{Al}_{2} \mathrm{O}_{3} \cdot \mathrm{H}_{2} \mathrm{O}$ will be used for convenience.

This compound belongs to the cubic system and has an index of 1.644. X-ray data are given in table 1 .

$2 \mathrm{BaO} \cdot \mathrm{Al}_{2} \mathrm{O}_{3} .5 \mathrm{H}_{2} \mathrm{O}$ - This compound is precipitated at boiling temperature from barium aluminate solutions over a wide range of concentration. It may be prepared readily by boiling a mixture of gibbsite and barium hydroxide solution, the concentration of the latter being of the order of $50 \mathrm{~g}$ $\mathrm{BaO}$ per liter. The hydrate forms a caked mass around the particles of gibbsite. If the solution is then filtered and the filtrate concentrated by boiling, a reasonably pure preparation of $2 \mathrm{BaO} . \mathrm{Al}_{2} \mathrm{O}_{3} .5 \mathrm{H}_{2} \mathrm{O}$ will be obtained. The product is coarse grained and relatively resistant to attack by water and dilute $\mathrm{HCl}$ (fig. 7). Analyses of two such preparations gave the molar ratios

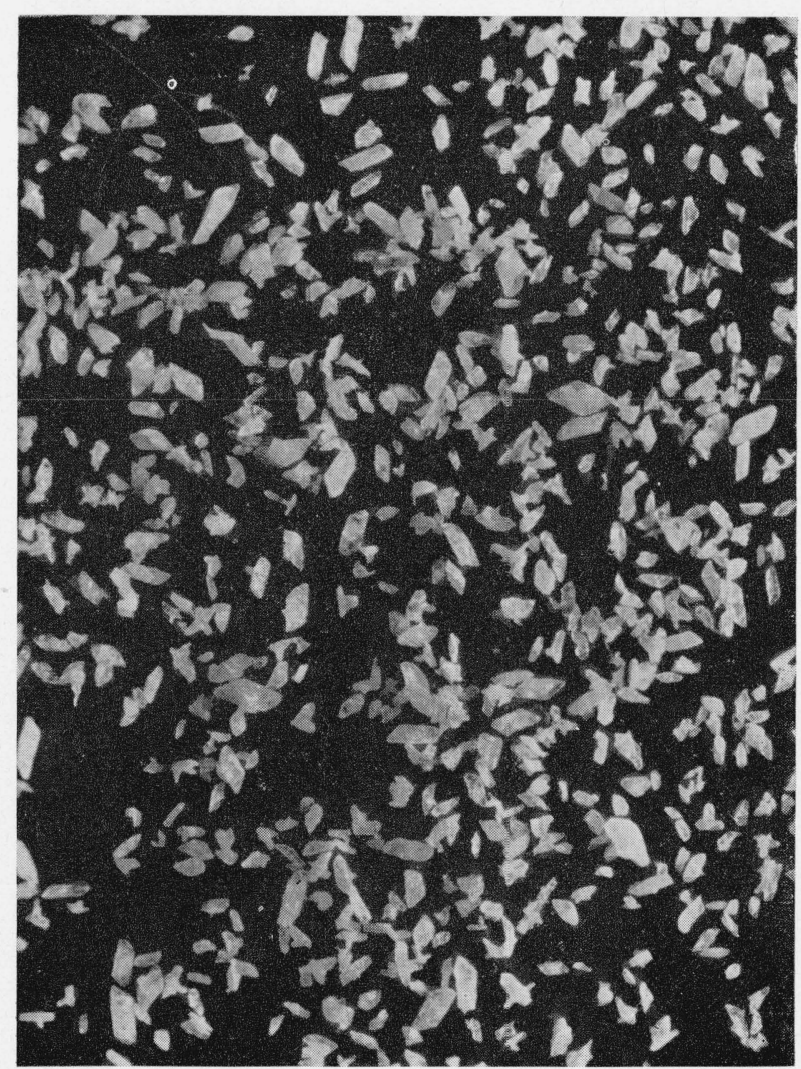

Figure 7. $2 \mathrm{BaO} . \mathrm{Al}_{2} \mathrm{O}_{3} .5 \mathrm{H}_{2} \mathrm{O}$.

Reflected light, magnification, $\times 11$ 
$1.96: 1: 4.85$ and $1.93: 1: 4.75$. The departure from a $2: 1: 5$ ratio probably is due to the presence of a small amount of hydrated alumina. Most of the water can be driven off below $250^{\circ} \mathrm{C}$.

The crystals are biaxial positive; indices are: $\alpha=1.642, \beta=1.655, \gamma=1.676$. The density is 3.42 . $\mathrm{X}$-ray data are given in table 1 .

Malquori's solubility diagram [2] indicates that $2 \mathrm{BaO} . \mathrm{Al}_{2} \mathrm{O}_{3} .5 \mathrm{H}_{2} \mathrm{O}$ is the stable solid phase in contact with barium aluminate solution over a certain range of concentration at $20^{\circ} \mathrm{C}$. In the present investigation it has been obtained only from boiling solutions; at $30^{\circ} \mathrm{C}$ only the $1: 1$ (or $1.1: 1$ ) barium aluminate hydrates have been precipitated, even from solutions saturated with respect to $\mathrm{Ba}(\mathrm{OH})_{2} .8 \mathrm{H}_{2} \mathrm{O}$. As a preliminary determination of the stability of the $2: 1: 5$ compound at room temperature, equal quantities of the solid were placed in contact with barium aluminate solutions of five different concentrations up to saturation with respect to $\mathrm{Ba}(\mathrm{OH})_{2} \cdot 8 \mathrm{H}_{2} \mathrm{O}$, and kept for several months. The solutions were analyzed from time to time. In every case, the solid dissolved slowly and incongruently with a slow increase in the ratio of $\mathrm{BaO}$ to $\mathrm{Al}_{2} \mathrm{O}_{3}$ in solution. These results require further confirmation but they strongly suggest that $2 \mathrm{BaO} \cdot \mathrm{Al}_{2} \mathrm{O}_{3} \cdot 5 \mathrm{H}_{2} \mathrm{O}$ is not stable in contact with barium aluminate solutions at room temperature. The slowness with which it reacts with water may easily lead to an erroneous assumption of equilibrium.

The X-ray powder diagrams and the photomicrographs were made by Mrs. E. Golovato and the thermal analyses by E. S. Newman, both of this Bureau.

\section{References}

[1] E. Beckmann, J. prakt. Chem. [2] 26, 385-421, 474503 (1882); 27, 126-152 (1883).

[2] G. Malquori, Gazz. Chim. ital. 56, 51 (1926).

[3] L. S. Wells, W. F. Clarke, and H. F. McMurdie, J. Research NBS 30, 367 (1943) RP1539.

[4] E. P. Flint, H. F. McMurdie, and L. S. Wells, J. Research NBS 21, 617 (1938) RP1147.

[5] E. Martin, Chimie \& industrie 23, 564 (1930).

Washington, April 14, 1948. 